\title{
Surveying Hungarian Teachers' Beliefs about Digital Game-based Learning
}

\author{
Lilla Bónus (Corresponding author) \\ Doctoral School of Education, University of Szeged, Szeged, Hungary \\ H-6722 Szeged, Petőfi S. sgt. 32-34. \\ E-mail: bonus.lilla@edu.u-szeged.hu \\ Erzsébet Antal \\ Biology Methodology Group, Department of Physiology, \\ Anatomy and Neuroscience, University of Szeged, Szeged, Hungary \\ H-6726 Szeged, Közép fasor 52. \\ E-mail: nagylne@bio.u-szeged.hu
}

Received: Sep. 7, $2021 \quad$ Accepted: Oct. 4, $2021 \quad$ Published: November 1, 2021

doi:10.5296/jse.v11i4.18992 URL: https://doi.org/10.5296/jse.v11i4.18992

\begin{abstract}
This study examines Hungarian teachers' beliefs and affective variables (confidence and motivation) in the context of digital game-based learning (DGBL). Our research questions were: How well does the Game-based-learning Teaching Belief Scale (GTBS) work among Hungarian teachers? What are Hungarian teachers' beliefs about DGBL? To what extent do background variables (teaching level, gender, age, teaching experience) influence teachers' beliefs about DGBL? We adapted the Game-based-learning Teaching Belief Scale to Hungarian. Primary and secondary school teachers $(\mathrm{N}=102)$ participating in our research completed the questionnaire online, in an anonymous form. Based on the results of the confirmatory factor analysis (CFA), we recommended deleting one item from the original questionnaire. The analyses were performed after deleting the item. Fillers have positive beliefs about DGBL, feel confident in applying DGBL, and are self-confident in their commitment to DGBL. Based on our results, teachers are happy to use digital educational games. Derived from the independent t-test, there is no significant difference in teachers'
\end{abstract}




\section{Aacrothink}

beliefs about DGBL by teaching level and gender. Furthermore, determined from the ANOVA, there is no significant difference in the Hungarian teachers' beliefs about DGBL by age and teaching experience. The results highlight that the teachers are open to reform their teaching practices and to apply new methods. This could be an important aspect of teacher training.

Keywords: digital game-based learning, beliefs, confidence, motivation 


\section{Introduction}

Nowadays, educational digital games are very popular, as they can be used in different forms for many learning purposes. They are suitable for increasing students' content knowledge and motivation, as well as having a positive effect on attitude and skill development (Srisawasdi \& Panjaburee, 2018; Tsai et al., 2019).

Although many pieces in the literature deal with the presentation of educational games (e.g., Alvarez et al., 2019; Prensky, 2001; Sousa \& Rocha, 2019; Wu, 2018), little is known about the beliefs of teachers in the field regarding digital game-based learning (DGBL). Whether and how teachers use technology in their teaching is mostly a matter of personal preference and decision. If we want to achieve changes in teaching practices, i.e., we want teachers to integrate technology into their teaching, we need to explore their beliefs about technology (Gilakjani, 2012). Digital game is a specific type of technology. The goal of games and development programs developed for educational purposes is to use them in practice. Thus, for successful development, we need to link theory with practice, i.e., we need to know teachers' beliefs about DGBL (Hsu et al., 2013; Hsu et al., 2017).

The literature sorts the barriers of integrating technology into lessons into two groups: first-order and second-order barriers. First-order barriers are extrinsic factors (resource types like equipment, time, and training) which are either deficient or inadequately provided (Ertmer, 1999; Means \& Olson, 1995). Second-order barriers are connected to teachers' beliefs about teaching and learning. These barriers are mostly responsible for hampering fundamental changes because they cannot be solved by providing resources (Ertmer, 1999; Kerr, 1996). Furthermore, an additional third-order barrier is also present in the lesson integration of technology, namely, the lack of design thinking by teachers (Chin-Chung \& Ching, 2012; Tsai \& Chai, 2012). The term "design thinking" is a combination of knowledge and practice at a level in which the advancement of information and communication technology (ICT) is associated with pedagogical benefits. It interprets and treats first- and second-order barriers as problems that can be solved through creative thinking (Tsai \& Chai, 2012).

Regarding DGBL, it can be stated that whether a teacher chooses to use a digital educational game can be influenced by the teacher's belief and confidence in and commitment to DGBL itself (Beavis, et al., 2014; Hsu et al., 2017). In addition to the factors listed above, it is important to mention that even though teachers may have adequate technological knowledge, they do not believe that DGBL can appear as an added value in the teaching/learning process (Blackwell et al., 2013). It is also conceivable that the teacher has a positive belief about digital educational games, but the school infrastructure does not allow the application, or the teacher is not confident enough in the application of the technology (Inan \& Lowther, 2010).

This study briefly reviews the literature on teachers' beliefs, presents the adaptation of GTBS to the Hungarian sample, and describes the results of its pilot study.

\section{Teachers' beliefs in relation to technology}

In examining teachers' beliefs, it has long been difficult to understand what the term means, 
how to define teachers' beliefs, and to determine what the difference is between knowledge and beliefs (Calderhead, 1996; Nespor, 1987).

Nespor (1987) suggests four characteristics to distinguish between knowledge and belief: (1) existential presumption, (2) alternativity, (3) affective and evaluative loading and (4) episodic structure. He also drafts two additional (affective and evaluative) aspects that help to understand how beliefs are organized into a system. Furthermore, Nespor emphasizes that the belief system relies much more on affective and evaluative components than the knowledge system.

Calderhead (1996) confirms that teachers' knowledge and beliefs do not mean the same thing. He treats belief as supposition, commitment, and ideology, while he refers to knowledge as factual propositions and understandings. This idea was also supported by Ertmer (2005). However, there are researchers who suggest that the two conceptions, knowledge, and belief, overlap (Murphy \& Mason, 2006).

Pajares's (1992) work is fundamental as he summarized the characteristics of teachers' belief in 16 points. Out of these characteristics, we would like to highlight that those beliefs that are formed early, persist for a long time and resist contradictions. Beliefs form a system and the earlier a belief is present in this system, the more enduring and resilient it is. The established system of beliefs is adaptive, and there is an order of priority between each two beliefs. It rarely changes in adulthood, and by the time students enter college, their beliefs about teaching are well established. All of this is significant because individuals' beliefs strongly influence their behaviour.

There is no accepted definition of teachers' beliefs about technology either. Park and Ertmer (2008) suppose that teacher beliefs about technology are a combination of self-efficacy, beliefs about the value of technology, and beliefs about teaching and learning technology. Therefore, whether a teacher uses or how he or she uses technology is influenced by teachers' beliefs about technology (Chen, 2010; Ertmer, 2005; Kim et al., 2013). If teachers perceive that technology tools are relevant to their educational goals, they are more likely to integrate these tools into their classroom practice (Vongkulluksn et al., 2018).

An important consideration in examining teachers' beliefs about technology is how student-centered technology integration is. Palak and Walls (2009) examined the relationship between teachers' beliefs and educational technology practice among teachers who use technology. They found that teachers most often use technology for preparation, management, and administration purposes, as well as to support their existing teacher-centered teaching practices. The use of technology to support student-centered teaching has proven to be rare. In another study, Ertmer, Ottenbreit-Leftwich, Sadik, Sendurur, and Sendurur (2012) specifically examined teachers with outstanding technological experience. Their study confirmed that teachers' classroom practice and pedagogical beliefs are closely aligned, therefore student-centered beliefs support student-centered practices. Furthermore, the teachers involved in the study believed that beliefs and attitudes about technology relevant to students' learning had the greatest impact on their success. This also means that the biggest constraint on the use of technology may be the pre-existing beliefs about the technology. 
The integration of technology has been associated with the application of constructivist pedagogy by many researchers (e.g., Hermans et al., 2008; Overbay et al., 2010). According to Overbay, Patterson, Vasu, and Grable (2010), teachers with constructivist educational practices, as well as teachers who believe that technology can be a useful tool in teaching, are more likely to use technology. However, the presence of technology alone does not imply its use in the classroom. This is well exemplified by the research of Windschitl and Sahl (2002), which monitored for two years how teachers integrate technology into classroom education. Researchers have found that this process is strongly related to the teacher's belief system. Important parts of this are the teacher's belief in students, what the teacher thinks about the elements of "good teaching" and the role of technology in the students' lives.

Although a teacher's beliefs are strongly related to how they integrate technology into their teaching practice (Chen, 2010; Ertmer, 2005; Kim, et al., 2013; Palak \& Walls, 2009), there may still be a contradiction between belief and practice. There could be three main reasons for this, (1) the impact of external factors, (2) limited or improper theoretical understanding of teachers, and (3) other conflicting beliefs of teachers (Chen, 2008). The first point called external factors by Chen (2008) corresponds to the first-order barriers by Ertmer (1999). The second point draws attention to the fact that the inconsistency between teachers' beliefs and practices is explained by a lack of theoretical understanding by teachers. The third point means teachers have conflicting beliefs in their belief system without being aware of this conflict (Chen, 2008).

In this study, belief refers to teachers' subjective and determined perspectives on DGBL. Confidence is the confidence and experience of teachers in using digital educational games. In the questionnaire used in our research, a subscale was named motivation, but motivation in this case refers to the commitment and willingness of teachers to accept DGBL in the future (Hsu et al., 2017).

\section{Purpose of the study and research questions}

This study examines Hungarian teachers' beliefs and affective variables (confidence and motivation) in the context of digital game-based learning (DGBL). The research questions of this study were as follows:

(1) How well does the GTBS questionnaire work for Hungarian teachers?

(2) What are Hungarian teachers' beliefs about DGBL?

(3) To what extent do background variables (teaching level, gender, age, teaching experience) influence teachers' beliefs about DGBL?

\section{Method}

The study follows the quantitative method strategy.

\subsection{Sample}

102 teachers (86 females, 16 males) participated in the measurement. The sample consists of 48 primary school, 49 secondary school, 5 primary and secondary school teachers. The 
average age was $47.32(\mathrm{SD}=10.23)$, and the average teaching experience was 21.81 years $(\mathrm{SD}=11.95)$. The sample was designed by contacting the heads of all primary and secondary schools in Szeged based on the National Educational Public Database and asking them to recommend the questionnaire to the teachers who work in their institution.

\subsection{Instrument}

The instrument used was the Game-based-learning Teaching Belief Scale (Hsu et al., 2017), which was adapted to Hungarian. The translation of the instrument from English into Hungarian was performed based on the back translation method.

The instrument is characterized by a seven-point Likert scale (ranging from strongly disagree to strongly agree). The original structure and reliability of the GTBS questionnaire is shown in Table 1. The background variables involved are the teaching level, gender, age, and teaching experience.

Table 1. The structure and reliability of GTBS (Hsu et al., 2017)

\begin{tabular}{lcc}
\hline \multicolumn{3}{l}{ Game-based-learning Teaching Belief Scale } \\
\hline \multicolumn{1}{c}{ Subscales } & $\mathrm{N}_{\text {items }}$ & Cronbach- $\alpha$ \\
\hline Belief & 3 & 0.83 \\
\hline Confidence & 3 & 0.87 \\
\hline Motivation & 3 & 0.86 \\
\hline Overall & 9 & 0.87 \\
\hline
\end{tabular}

\subsection{Procedures}

The questionnaire was recorded online (Google forms), and the response was anonymous. We use SPSS 22 and Jamovi 1.6.8. for data analysis. Mean and standard deviation were calculated from the values on the Likert scale.

To confirm the validity of the questionnaire, we performed confirmatory factor analysis (CFA) and exploratory factor analysis (EFA). The reliability of the questionnaire was estimated by calculating Cronbach- $\alpha$. To explore whether there is a difference in teachers' beliefs about DGBL based on teaching level and gender, we conducted independent t-tests. To explore whether there is a difference in teachers' beliefs about DGBL based on age and teaching experience, we conducted ANOVA. Correlations were performed to explore the relationships between age, teaching experience, and GBTS subscales.

\section{Results and discussion}

5.1 Research Question 1: How well does the GTBS questionnaire work for Hungarian teachers?

The structure of the theoretical model for the GTBS questionnaire (Hsu et al., 2017) is shown in Figure 1. The circles contain the latent variables, the squares contain the individual questionnaire items, and the arrows indicate the relationships. 


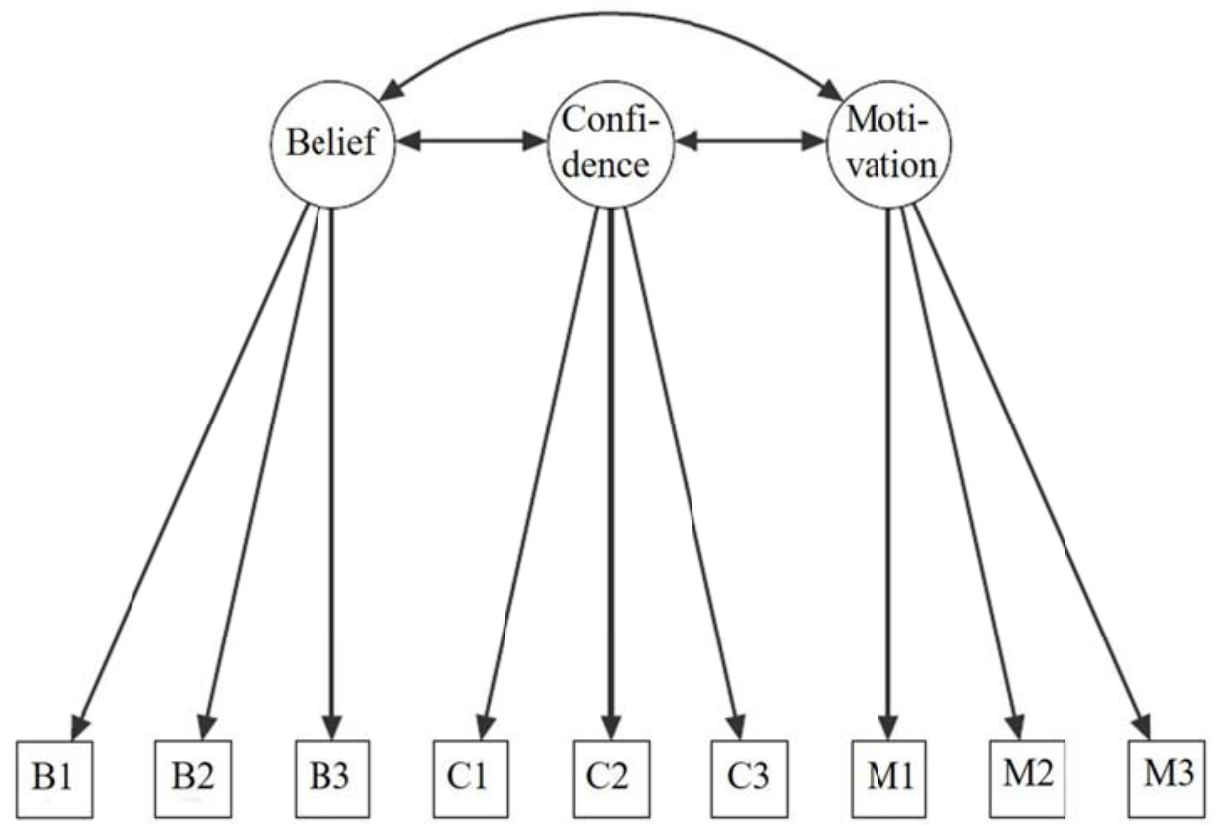

Figure 1. Theoretical model: The structure of GTBS (Hsu et al., 2017)

Note: Items $\mathrm{C} 1, \mathrm{C} 2, \mathrm{C} 3$ and $\mathrm{M} 1$ are phrased in a negative manner

The following model fit indices were used in the confirmatory factor analysis: Chi-square goodness of fit divided by the degrees of freedom $\left(\chi^{2} / \mathrm{df}\right)$, root mean square error of approximation (RMSEA), standardized root mean square residual (SRMR), comparative fit index (CFI), and Tucker-Lewis index (TLI) (Brown, 2006; Hu \& Bentller, 1999; Wang \& Wang, 2012). We use $\chi^{2} / \mathrm{df}$ instead of $\chi^{2}$, because the value of $\chi^{2}$ is highly dependent on the sample size. The effect of sample size on $\chi^{2}$ can be reduced by dividing its value by the number of degrees of freedom. The ideal range for the value of the indices thus obtained is between 1.00 and 3.00 (Glynn et al., 2011).

The model fit indices, its values, and recommendations are listed in Table 2. Although the SRMR and CFI values are good, based on the other indices, the model fit is inadequate. Therefore, a modification of the model is necessary.

Table 2. Fit indices of GTBS

\begin{tabular}{cccc}
\hline Fit indices & GTBS & Recommendation & Model fit \\
\hline$\chi^{2} / \mathrm{df}$ & 3.14 & $\leq 3.00$ & not fit \\
\hline RMSEA & 0.145 & $\leq 0.08$ & not fit \\
\hline SRMR & 0.077 & $\leq 0.08$ & good \\
\hline CFI & 0.902 & Perfect $\geq 0.95 \geq$ Good $\geq 0.90$ & good \\
\hline TLI & 0.853 & $0.90<$ TLI $<0.95$ & not fit \\
\hline
\end{tabular}

The wording of the M3 questionnaire item differs from the wording of the other two items in the subscale. Therefore, we deleted it and re-checked the fit indices of the questionnaire. With 
the deletion of item M3, the model fit indices improved significantly. After deleting item M3, the construct validity proved to be good. The result of the CFA after deletion of item M3 is shown in Table 3.

Table 3. Fit indices of GTBS without M3

\begin{tabular}{cccc}
\hline Fit indices & GTBS & Recommendation & Model fit \\
\hline$\chi^{2} / \mathrm{df}$ & 1.73 & $\leq 3.00$ & good \\
\hline RMSEA & 0.080 & $\leq 0.08$ & acceptable \\
\hline SRMR & 0.058 & $\leq 0.08$ & good \\
\hline CFI & 0.970 & Perfect $\geq 0.95 \geq$ Good $\geq 0.90$ & perfect \\
\hline TLI & 0.950 & $0.90<$ TLI $<0.95$ & good \\
\hline
\end{tabular}

An exploratory factor analysis (EFA) was then performed $\left(\mathrm{KMO}=0.80 ; \mathrm{R}^{2}=68\right)$. The EFA confirms the results of the CFA. The reliability coefficients (Cronbach- $\alpha$ ) were $0.88,0.94$, 0.74, respectively for the Belief, Confidence and Motivation subscales, and 0.85 for the overall scale. That means the internal consistency is good. All further analysis was performed after deleting M3 item.

\subsection{Research Question 2: What are Hungarian teachers'beliefs about DGBL?}

To answer this research question, we calculated mean and standard deviation. Fillers expressed their agreement with the statements, which means that they have a positive belief about DGBL; they are committed to and confident about their application (Table 4). This is an important result because teachers' experience, personal playing experience, interest in technology and ICT-related self-efficacy play a significant role in shaping attitudes towards DGBL, which determines whether teachers introduce a pedagogical innovation into their practice (Ailincai \& Gabillon, 2018; Kaimara et al., 2021). This is also supported by the fact that the adoption and the effectiveness of DGBL depend on the acceptance by teachers (Bourgonjon et al., 2013).

Table 4. Mean and standard deviation of the values given on the Likert scale for the GTBS subscales

\begin{tabular}{ccc}
\hline Subscales & Mean & SD \\
\hline Belief & 5.66 & 1.13 \\
\hline Confidence & 5.54 & 1.34 \\
\hline Motivation1+2 & 5.85 & 1.44 \\
\hline
\end{tabular}

5.3 Research Question 3: To what extent do background variables (teaching level, gender, age, teaching experience) influence teachers' beliefs about digital game-based learning?

We conducted independent t-tests to explore whether teachers' teaching level (primary or secondary school) and gender influenced their beliefs about DGBL. In neither case did we find a significant difference. This means that it could not be confirmed that in comparison with secondary school teachers, the elementary school teachers have higher self-efficacy or 
demonstrate stronger beliefs, confidence, and motivation to use games in their classes (Hsu et al., 2020). Although teaching with digital games is more common among primary school teachers (Bourgonjon et al., 2013; Proctor \& Marks, 2013), the Hungarian sample does not show this difference in the beliefs of secondary school teachers. In the case of gender, Hsu, Tsai, Chang, and Liang (2017) found no significant differences either. Although some researchers have reported that male teachers are more highly skilled at utilising ICT resources and tools than female teachers (Kaarakainen et al., 2018), this difference does not appear in their belief in DGBL (Jang \& Tsai, 2012). This result is also because there were far more women than men in the sample, which is a good representation of the Hungarian teacher society. The results of the independent t-test by teaching level are shown in Table 5, and the results of the independent t-test by gender are shown in Table 6 .

Table 5. Primary and secondary school teachers' beliefs about DGBL

\begin{tabular}{|c|c|c|c|c|c|c|c|}
\hline \multirow[t]{2}{*}{ Parameters } & \multirow{2}{*}{$\begin{array}{l}\text { Statistical } \\
\text { indicators }\end{array}$} & \multirow{2}{*}{$\begin{array}{l}\text { Primary } \\
\text { school } \\
\text { teachers } \\
\mathrm{N}=47\end{array}$} & \multirow{2}{*}{$\begin{array}{c}\text { Secondary } \\
\text { school teachers } \\
\mathrm{N}=49\end{array}$} & \multicolumn{2}{|c|}{ F-probe } & \multicolumn{2}{|c|}{$\begin{array}{c}\mathrm{t} \text { test } \\
\text { analysis }\end{array}$} \\
\hline & & & & $\mathrm{F}$ & $\mathrm{P}$ & $|t|$ & $\mathrm{p}$ \\
\hline \multirow{2}{*}{ Belief } & Mean & 5.72 & 5.59 & \multirow{2}{*}{2.80} & \multirow{2}{*}{0.10} & \multirow{2}{*}{0.60} & \multirow{2}{*}{ n.s. } \\
\hline & $\mathrm{SD}$ & 1.06 & 1.23 & & & & \\
\hline \multirow{2}{*}{ Confidence } & Mean & 5.73 & 5.31 & \multirow{2}{*}{0.42} & \multirow{2}{*}{0.52} & \multirow{2}{*}{1.50} & \multirow{2}{*}{ n.s. } \\
\hline & $\mathrm{SD}$ & 1.26 & 1.46 & & & & \\
\hline \multirow{2}{*}{ Motivation $1+2$} & Mean & 5.99 & 5.66 & \multirow{2}{*}{0.36} & \multirow{2}{*}{0.55} & \multirow{2}{*}{0.28} & \multirow{2}{*}{ n.s. } \\
\hline & SD & 1.36 & 1.54 & & & & \\
\hline
\end{tabular}

Table 6 . Teachers' beliefs about digital game-based learning by gender

\begin{tabular}{|c|c|c|c|c|c|c|c|}
\hline \multirow[b]{2}{*}{ Parameters } & \multirow[b]{2}{*}{ Statistical indicators } & \multirow{2}{*}{$\begin{array}{c}\text { Female } \\
\mathrm{N}=86\end{array}$} & \multirow{2}{*}{$\begin{array}{l}\text { Male } \\
\mathrm{N}=16\end{array}$} & \multicolumn{2}{|c|}{ F-probe } & \multicolumn{2}{|c|}{$\mathrm{t}$ test analysis } \\
\hline & & & & $\mathrm{F}$ & $\mathrm{P}$ & $|t|$ & $\mathrm{p}$ \\
\hline \multirow{2}{*}{ Belief } & Mean & 5.64 & 5.77 & \multirow{2}{*}{2.06} & \multirow{2}{*}{0.15} & \multirow{2}{*}{0.41} & \multirow{2}{*}{ n.s. } \\
\hline & SD & 1.07 & 1.46 & & & & \\
\hline \multirow{2}{*}{ Confidence } & Mean & 5.61 & 5.14 & \multirow{2}{*}{0.09} & \multirow{2}{*}{0.77} & \multirow{2}{*}{1.28} & \multirow{2}{*}{ n.s } \\
\hline & $\mathrm{SD}$ & 1.30 & 1.54 & & & & \\
\hline \multirow{2}{*}{ Motivation $1+2$} & Mean & 5.96 & 5.22 & \multirow{2}{*}{3.66} & \multirow{2}{*}{0.06} & \multirow{2}{*}{1.92} & \multirow{2}{*}{ n.s } \\
\hline & $\mathrm{SD}$ & 1.35 & 1.77 & & & & \\
\hline
\end{tabular}

A one-way ANOVA was performed to reveal whether there is a significant difference in GTBS subscales by age. Hsu, Tsai, Chang, and Liang (2017) used three categories to group teachers by age. However, $77.45 \%$ of our sample would belong to the same category, therefore, we changed those groups and divided teachers into four categories based on age $(1=21-30 ; 2=31-40 ; 3=41-50,4=51-65)$. Category formation was modelled on international pedagogical research, as these are the age groups based on which we can expect a difference in the case of GTBS subscales (Hsu et al., 2017; Lin et al., 2013). Just as Hsu, Tsai, Chang, 
and Liang (2017), we found that there was no significant difference between the subscales (Table 7). We expected younger teachers to be more confident about DGBL (Lin et al., 2013), because higher age may be associated with higher levels of perceiving the problems and barriers of ICT use (Scherer et al., 2015). The fact that there is no difference may be due to the high proportion of teachers in the sample who are genuinely committed to the teaching profession and therefore strive to maintain and update their knowledge on an ongoing basis.

Table 7. The results of ANOVA on GTBS subscales by different age groups

\begin{tabular}{|c|c|c|c|c|c|c|c|c|c|c|}
\hline \multirow{3}{*}{ Parameters } & \multicolumn{8}{|c|}{ Age level } & \multicolumn{2}{|c|}{ Variance analysis } \\
\hline & \multicolumn{2}{|c|}{$\begin{array}{c}\text { (1) } 21-30 \\
\mathrm{~N}=11\end{array}$} & \multicolumn{2}{|c|}{$\begin{array}{c}\text { (2) } 31-40 \\
\mathrm{~N}=12\end{array}$} & \multicolumn{2}{|c|}{$\begin{array}{c}\text { (3) } 41-50 \\
\mathrm{~N}=35\end{array}$} & \multicolumn{2}{|c|}{$\begin{array}{c}\text { (4) } 51-65 \\
N=44\end{array}$} & \multirow{2}{*}{$\mathrm{F}$} & \multirow{2}{*}{$\mathrm{p}$} \\
\hline & Mean & $\mathrm{SD}$ & Mean & SD & Mean & SD & Mean & $\mathrm{SD}$ & & \\
\hline Belief & 5.79 & 1.36 & 5.36 & 0.87 & 5.49 & 1.32 & 5.85 & 0.95 & 0.98 & n.s. \\
\hline Confidence & 6.09 & 0.65 & 4.92 & 1.60 & 5.59 & 1.49 & 5.53 & 1.24 & 1.52 & n.s. \\
\hline Motivation $1+2$ & 6.18 & 1.75 & 5.75 & 1.21 & 5.91 & 1.34 & 5.74 & 1.53 & 0.32 & n.s. \\
\hline
\end{tabular}

A further one-way analysis of variance was performed to examine whether there is a difference between the GTBS subscales based on teaching experience. Teachers were divided into three subsamples based on the number of years spent teaching $(1=0-10,2=11-20 ; 3=21$ or more). Based on Hsu, Tsai, Chang, and Liang (2017) we expected to find significant differences in belief and motivation based on teaching experiences. Furthermore, according to Lin, Tsai, Chai, and Lee (2013), older in-service science teachers have less confidence in embedding technology into their teaching. However, we did not find any significant differences based on teaching experience either (Table 8). This result can be explained by the fact that age and teaching experience are strongly interrelated.

Table 8. The results of ANOVA on GTBS subscales by different teaching experience

\begin{tabular}{|c|c|c|c|c|c|c|c|c|}
\hline \multirow{3}{*}{ Parameters } & \multicolumn{6}{|c|}{ Teaching experience } & \multicolumn{2}{|c|}{ Variance analysis } \\
\hline & \multicolumn{2}{|c|}{$\begin{array}{c}\text { (1) } 0-10 \\
\mathrm{~N}=21\end{array}$} & \multicolumn{2}{|c|}{$\begin{array}{c}\text { (2) } 11-20 \\
\mathrm{~N}=22\end{array}$} & \multicolumn{2}{|c|}{$\begin{array}{c}(3) \geq 21 \\
\mathrm{~N}=59\end{array}$} & \multirow{2}{*}{$\mathrm{F}$} & \multirow{2}{*}{$\mathrm{p}$} \\
\hline & Mean & SD & Mean & SD & Mean & $\mathrm{SD}$ & & \\
\hline Belief & 5.51 & 1.13 & 5.36 & 1.48 & 5.83 & 0.95 & 1.64 & n.s. \\
\hline Confidence & 5.41 & 1.35 & 5.60 & 1.55 & 5.56 & 1.28 & 0.13 & n.s. \\
\hline Motivation1+2 & 5.98 & 1.55 & 5.89 & 1.34 & 5.79 & 1.46 & 0.14 & n.s. \\
\hline
\end{tabular}

We considered it important to examine whether demographic variables correlate with subsets of the GTBS questionnaire. Therefore, Pearson correlations were calculated. We did not find correlation between demographic variables and GTBS subscales, which is consistent with the fact that we did not find a significant difference in teachers' beliefs based on the background 
variables.

\section{Limitation}

We could not present a sample of the same size based on age and gender. Most of the sample consists of elder teachers and women. At the same time, it well reflects the composition of the Hungarian pedagogical society.

\section{Conclusion}

Based on our results, it can be stated that when applying the GTBS questionnaire to the Hungarian sample, it should be considered that we may experience differences compared to the original questionnaire structure. However, after deleting M3 item, the instrument will function properly.

Analysing the sample along the structure proposed in the confirmatory and exploratory factor analysis, we found that teachers' belief about DGBL is positive, they are willing to apply it, and are confident in its application. However, it should be kept in mind that completing the online questionnaire acts as a kind of filter, as only teachers who show interest in the topic might have completed the questionnaire. This is supported by the fact that $81.4 \%$ of respondents indicated that they use digital educational games in their teaching practice.

We found no significant difference in beliefs about DGBL based on the background variables involved, i.e., teaching level, gender, age, and teaching experience. The results highlight that the teachers are open to reform their teaching practices and to apply new methods. This could be an important aspect of teacher training.

However, not only the beliefs are important, but knowledge about DGBL is also crucial. Therefore, we consider it important to expand the research by examining the technological pedagogical content knowledge of Hungarian teachers.

\section{Acknowledgments}

We are extremely grateful to the teachers who participated in the research reported here.

\section{References}

Ailincai, R., \& Gabillon, Z. (2018). Analysing Teachers' Representations of Digital Technology Using a Grounded Theory Approach. EURASIA Journal of Mathematics, Science and Technology Education, 14(10), 1-18. https://doi.org/10.29333/ejmste/93380

Alvarez, J., Irrmann, O., Djaouti, D., Taly, A., Rampnoux, O., \& Sauvé, L. (2019). Design Games and Game Design: Relations Between Design, Codesign and Serious Games in Adult Education. In S. Leleu-Merviel, D. Schmitt \& P. Useille (Eds.), From UXD to LivXD: Living eXperience Design (pp. 229-253). John Wiley \& Sons. https://doi.org/10.1002/9781119612254.ch11

Beavis, C., Rowan, L., Dezuanni, M., McGillivray, C., O’Mara, J., Prestridge, S., Stieler-Hunt, C., Thompson, R., \& Zagami, J. (2014). Teachers' Beliefs about the Possibilities and Limitations of Digital Games in Classrooms. E-Learning and Digital Media, 11(6), 
569-581. http://dx.doi.org/10.2304/elea.2014.11.6.569

Blackwell, C. K., Lauricella, A. R., Wartella, E., Robb, M., \& Schomburg, R. (2013). Adoption and use of technology in early education: The interplay of extrinsic barriers and teacher attitudes. Computers \& Education, 69, 310-319. https://doi.org/10.1016/j.compedu.2013.07.024

Bourgonjon, J., De Grove, F., De Smet, C., Van Looy, J., Soetaert, R., \& Valcke, M. (2013). Acceptance of game-based learning by secondary school teachers. Computers \& Education, 67, 21-35. https://doi.org/10.1016/j.compedu.2013.02.010

Brown, T. A. (2006). Confirmatory factor analysis for applied research. Guilford publications.

Calderhead, J. (1996). Teachers: Beliefs and knowledge. In D. Berliner \& R. Calfee (Eds.), Handbook of Educational Psychology (pp. 709-725). Macmillan Library Reference.

Chen, C-H. (2008). Why Do Teachers Not Practice What They Believe Regarding Technology Integration? The Journal of Educational Research, 102(1), 65-75, http://dx.doi.org/10.3200/JOER.102.1.65-75

Chen, R-J. (2010). Investigating model for preservice teachers' use of technology to support student-centered learning. Computers \& Education, 55(1), 32-42. https://doi.org/10.1016/j.compedu.2009.11.015

Chin-Chung, T., \& Ching, S. C. (2012). The "third"-order barrier for technology-integration instruction: Implications for teacher education. Australasian Journal of Educational Technology, 28(6), 1057-1060. https://doi.org/10.14742/ajet.810

Ertmer, P. A. (1999). Addressing first- and second-order barriers to change: strategies for technology integration. Educational Technology Research and Development, 47(4), 47-61. https://doi.org/10.1007/BF02299597

Ertmer, P. A. (2005). Teacher pedagogical beliefs: the final frontier in our quest for technology integration? Educational Technology Research and Development, 53(4), 25-39. https://doi.org/10.1007/BF02504683

Ertmer, P. A., Ottenbreit-Leftwich, A. T., Sadik, O., Sendurur, E., \& Sendurur, P. (2012). Teacher beliefs and technology integration practices: A critical relationship. Computers \& Education, 59(2), 423-435. https://doi.org/10.1016/j.compedu.2012.02.001

Gilakjani, A. P. (2012). EFL Teachers' Beliefs toward Using Computer Technology in English Language Teaching. Journal of Studies in Education, 2(2), 62-80. http://dx.doi.org/10.5296/jse.v2i2.1174

Glynn, S. M., Brickman, P., Armstrong, N., \& Taasoobshirazi, G. (2011). Science Motivation Questionnaire II: Validation with Science Majors and Nonscience Majors. Journal of Research in Science Teaching, 48(10), 1159-1176. https://doi.org/10.1002/tea.20442

Hermans, R., Tondeur, J., van Braak, J., \& Valcke, M. (2008). The impact of primary school 
teachers' educational beliefs on the classroom use of computers. Computers \& Education, 51(4), 1499-1509. https://doi.org/10.1016/j.compedu.2008.02.001

Hsu, C.-Y., Liang, J.-C., \& Tsai, M.-J. (2020). Probing the structural relationships between teachers' beliefs about game-based teaching and their perceptions of technological pedagogical and content knowledge of games. Technology, Pedagogy and Education, 29(3), 1-13. https://doi.org/10.1080/1475939x.2020.1752296

Hsu, C.-Y., Liang, J.-C., Chai, C.-S., \& Tsai, C.-C. (2013). Exploring preschool teachers' technological pedagogical content knowledge of educational games. Journal of Educational Computing Research, 49(4), 461-479. https://doi.org/10.2190/EC.49.4.c

Hsu, C.-Y., Tsai, M.-J., Chang, Y.-H., \& Liang, J.-C. (2017). Surveying In-Service Teachers' Beliefs about Game-Based Learning and Perceptions of Technological Pedagogical and Content Knowledge of Games. Educational Technology \& Society, 20(1), 134-143.

Hu, L., \& Bentler, P. M. (1999). Cutoff criteria for fit indexes in covariance structure analysis: Conventional criteria versus new alternatives. Structural Equation Modeling, 6(1), 1-55. https://doi.org/10.1080/10705519909540118

Inan, F., \& Lowther, D. (2010). Laptops in K-12 classrooms: exploring factors impacting use. Computers \& Education, 55(3), 937-944. https://doi.org/10.1016/j.compedu.2010.04.004

Jang, S-J., \& Tsai, M-F. (2012). Exploring the TPACK of Taiwanese elementary mathematics and science teachers with respect to use of interactive whiteboards. Computers \& Education, 59(2), 327-338. https://doi.org/10.1016/j.compedu.2012.02.003

Kaarakainen, M-T., Kivinen, O., \& Vainio, T. (2018). Performance-based testing for ICT skills assessing: a case study of students and teachers' ICT skills in Finnish schools. Universal Access in the Information Society, 17(2), 349-360. https://doi.org/10.1007/s10209-017-0553-9

Kaimara, P., Fokides, E., Oikonomou, A., \& Deliyannis, I. (2021). Potential Barriers to the Implementation of Digital Game-Based Learning in the Classroom: Pre-service Teachers' Views. Technology, Knowledge and Learning. https://doi.org/10.1007/s 10758-021-09512-7

Kerr, S. T. (1996). Visions of sugarplums: The future of technology, education, and the schools. In S. T. Kerr (Ed.), Technology and the future of schooling: Ninety-fifth yearbook of the National Society for the Study of Education (part 2) (pp. 1-27). University of Chicago Press.

Kim, C., Kim, M. K., Lee, C., Spector, J. M., \& DeMeester, K. (2013). Teacher beliefs and technology integration. Teaching and Teacher Education, 29(1), 76-85. https://doi.org/10.1016/j.tate.2012.08.005

Lin, T.-C., Tsai, C.-C., Chai, C. S., \& Lee, M.-H. (2013). Identifying science teachers' perceptions of technological pedagogical and content knowledge (TPACK). Journal of $\begin{array}{llll}\text { Science Education } \quad \text { and } & \text { 325-336. }\end{array}$ https://doi.org/10.1007/s10956-012-9396-6 
Means, B., \& Olson, K. (1995). Technology and education reform: Technical research report. SRI International.

Murphy, P., \& Mason, L. (2006). Changing knowledge and beliefs. In P. A. Alexander \& P. H. Winne (Eds.), Handbook of educational psychology (2nd edition) (pp. 305-324). Routledge.

Nespor, J. (1987). The role of beliefs in the practice of teaching. Journal of Curriculum Studies, 19(4), 317-328. https://doi.org/10.1080/0022027870190403

Overbay, A., Patterson, A. S., Vasu, E. S., \& Grable, L. L. (2010). Constructivism and technology use: findings from the IMPACTing Leadership project. Educational Media International, 47(2), 103-120. https://doi.org/10.1080/09523987.2010.492675

Pajares, M. F. (1992). Teachers' beliefs and educational research: cleaning up a messy construct. Review of Educational Research, 62(3), 307-332. https://doi.org/10.3102/00346543062003307

Palak, D., \& Walls, R. T. (2009). Teachers' Beliefs and Technology Practices: A Mixed-methods Approach. Journal of Research on Technology in Education, 41(4), 417-441. https://doi.org/10.1080/15391523.2009.10782537

Park, S. H., \& Ertmer, P. A. (2008). Impact of problem-based learning (PBL) on teachers' beliefs regarding technology use. Journal of Research on Technology in Education, 40(2), 247-267. https://doi.org/10.1080/15391523.2007.10782507

Prensky, M. (2001). Fun, Play and Games: What Makes Games Engaging. McGraw-Hill.

Proctor, M. D., \& Marks, Y. (2013). A survey of exemplar teachers' perceptions, use, and access of computer-based games and technology for classroom instruction. Computers \& Education, 62, 171-180. http://dx.doi.org/10.1016/j.compedu.2012.10.022

Scherer, R., Siddiq, F., \& Teo, T. (2015). Becoming more specific: Measuring and modeling teachers' perceived usefulness of ICT in the context of teaching and learning. Computers \& Education, 88, 202-214. https://doi.org/10.1016/j.compedu.2015.05.005

Sousa, J., \& Rocha, Á. (2019). Leadership styles and skills developed through game-based learning. Journal of Business Research, 94, 360-366. https://doi.org/10.1016/j.jbusres.2018.01.057

Srisawasdi, N., \& Panjaburee, P. (2018). Implementation of Game-transformed Inquiry-based Learning to Promote the Understanding of and Motivation to Learn Chemistry. Journal of Science Education and Technology, 28(2), 152-164. https://doi.org/10.1007/s10956-018-9754-0

Tsai, C-Y., \& Chai, C. S. (2012). The "third"-order barrier for technology-integration instruction: Implications for teacher education. Australasian Journal of Educational Technology, 28(6), 1057-1060. https://doi.org/10.14742/ajet.810

Tsai, C-Y., Lan, H-S., \& Liu, S. C. (2019). The effect of pedagogical GAME model on students' PISA scientific competencies. Journal of Computer Assisted Learning, 36(3), 
359-369. https://doi.org/10.1111/jcal.12406

Vongkulluksn, V. W., Xie, K., \& Bowman, M. A. (2018). The role of value on teachers' internalization of external barriers and externalization of personal beliefs for classroom technology integration. Computers \& Education, 118(1), 70-81. https://doi.org/10.1016/j.compedu.2017.11.009

Wang, J., \& Wang, X. (2012). Structural equation modeling: Applicationsi using Mplus. John Wiley \& Sons. https://doi.org/10.1002/9781118356258

Windschitl, M., \& Sahl, K. (2002). Tracing teachers' use of technology in a laptop computer school: The interplay of teacher beliefs, social dynamics, and institutional culture. American Educational Research Journal, 39(1), 165-205. https://doi.org/10.3102/00028312039001165

Wu, M. L. (2018). Making Sense of Digital Game-Based Learning: A Learning Theory-Based Typology Useful for Teachers. Journal of Studies in Education, 8(4), 1-14. https://doi.org/10.5296/jse.v8i4.13022

\section{Copyrights}

Copyright for this article is retained by the author(s), with first publication rights granted to the journal.

This is an open-access article distributed under the terms and conditions of the Creative Commons Attribution license (http://creativecommons.org/licenses/by/4.0/) 